\title{
Foreword
}

THE FIRST SESSION of the Legislature of the Territory of Hawaii to meet after America's entrance into World War II passed a joint resolution in the spring of 1943 providing for the collection and preservation of material relating to Hawaii's part in the war and designating the University of Hawaii as the depository for such material. As a result of this legislation, the Hawaii War Records Depository was established. During the six years of its existence, it has amassed a wide variety of important material from every conceivable source.

In 1947 the legislature authorized the preparation and publication of a one-volume history of Hawaii's part in the war. Hawaii's War Years, 1941-1945, the result of that mandate, has been prepared under the direction of the Hawaii War Records Committee of the University of Hawaii.

Hawaii's War Years is a straightforward, factual account of what Hawaii did in the war and the effect of the war upon Hawaii, with emphasis on civilian activities and problems. The most difficult tasks in its preparation have been the selection of material and the condensation of material selected to readable limits. Many interesting details have been omitted and many stories of achievement left untold, for each chapter in itself might well have been expanded into a separate book.

Every effort has been made to insure both accuracy of statement and correctness of interpretation. Almost every statement rests on tangible documentary evidence. Suggestions have been sought from key persons in certain fields of war activity who have read chapters concerning which they had firsthand knowledge. However, despite all precautions, it is inevitable that some errors will be found. Some records are still "classified," some are unavailable in Hawaii, some prepared under wartime stress contain errors and contradictions. Documentation upon which the book is based, keyed to the text by page and line, may be obtained from the University of Hawaii Press. 
Many persons have contributed to this history. Hundreds have given or loaned materials to the War Records Depository; others have supplied information through personal interviews or letters. Members of the staffs of the Archives of Hawaii, the Library of Hawaii, and the University of Hawaii Library-especially the Hawaiiana Room and the Government Documents Collection-aided in finding information not available in the War Records Depository. Delegate Joseph R. Farrington and his secretary, Mrs. Margaret C. Turner, have been helpful in making Washington contacts.

Catharine P. Field, the first director of the depository, the late Major Vivian M. Culver, Adele Culver, Ethel M. Prescott, and other former members of the depository staff, laid the groundwork for the study. Kathryn H. Stidham, archivist for several years, handled the task of collecting the enormous bulk of material. Lloyd L. Lee, research assistant at the depository, aided in preparing the chronology and bibliography and in checking the references, of which there are more than 3,000. Kasumi Murakami and Dorothy Caires also assisted in many details.

Members of the staffs of the Office of Publications and Information of the University of Hawaii and the University of Hawaii Press have offered valuable editorial suggestions. The final selection of photographs from several thousand prints, the writing of captions, much of the preparation of the bibliography, and the compilation of the index was done by the press staff.

Dr. Thomas D. Murphy, chairman of the depository committee, has given much assistance and advice throughout the entire project, and other members of the committee have been helpful.

\section{GWENFreAD ALLEN}

Honolulu, Hawaii

June, 1949 